\title{
The Effect of Alanine on Glucagon Secretion
}

\author{
Walter A. Müller, Gerald R. Faloona, and Roger H. Unger \\ From the Department of Internal Medicine, The University of Texas \\ (Southwestern) Medical School at Dallas, and Veterans Administration \\ Hospital, Dallas, Texas 75216
}

A B S T R A C T If glucagon plays a hormonal role in the regulation of gluconeogenesis from endogenous amino acids, its secretion might be stimulated by an increase in the concentration of alanine, which has recently been identified as a principal gluconeogenic precursor. To determine if this is the case, 0.75 mmole of alanine per kilo was infused into conscious dogs immediately after a priming injection of 0.25 mmole per $\mathrm{kg}$ for $15 \mathrm{~min}$. A uniform rise in the plasma level of pancreatic glucagon, as determined by a relatively specific radioimmunoassay for pancreatic glucagon, was observed. The rise, which averaged $90 \mathrm{pg}$ per $\mathrm{ml}$, was highly significant at $7 \frac{1}{2}$ and $15 \mathrm{~min}$ after the start of the infusion. Insulin rose an average of only $8 \mu \mathrm{U}$ per $\mathrm{ml}$, while glucose rose an average of $10 \mathrm{mg}$ per $100 \mathrm{ml}$. A lower dose of alanine, 1 mmole per $\mathrm{kg}$, infused over a $1 \mathrm{hr}$ period without an initial priming injection, also elicited a significant rise in glucagon measured in the pancreaticoduodenal venous plasma; glucagon rose from $350 \mathrm{pg}$ per $\mathrm{ml}$ to $1066 \mathrm{pg}$ per $\mathrm{ml}$ at the end of the infusion. The insulin response was modest and inconsistent, and glucose, again, rose $10 \mathrm{mg}$ per $100 \mathrm{ml}$.

To determine if the availability of exogenous glucose would abolish the alanine-induced rise in glucagon secretion, dogs were made hyperglycemic by a constant intravenous glucose infusion and were then given the high-dose alanine infusion. Under these circumstances, glucagon did not rise above the mean fasting concentration of $75 \mathrm{pg}$ per $\mathrm{ml}$, whereas mean insulin rose dramatically by more than $100 \mu \mathrm{U}$ per ml.

It was concluded that, in the fasting state, alanine does stimulate the secretion of glucagon, while having very little stimulatory effect on insulin secretion. Glucagon could, therefore, be a humoral mediator of gluconeogenesis from endogenous alanine, responding to

This work was presented at the Central Society for Clinical Research Annual Meeting, 5 November 1970, Chicago, Ill. and at the American Federation for Clinical Research, 1-2 May 1971, Atlantic City, N. J.

Dr. Müller is a Fellow of the Swiss National Fund.

Received for publication 2 April 1971. hyperalaninemia in the fasting state, but not when exogenous glucose is available.

\section{INTRODUCTION}

Although the potent gluconeogenic action of glucagon has long been appreciated, experimental support for alpha cell stimulation by glucose precursors is limited entirely to studies demonstrating that arginine and arginine-containing amino acid mixtures are a powerful stimulus to glucagon secretion $(1,2)$. However, Felig, Pozefsky, Marliss, and Cahill have reported that alanine is a major gluconeogenic precursor (3); this would seem to invalidate teleologic inferences concerning glucagon's role in endogenous gluconeogenesis based upon the alpha cell response to amino acids such as arginine. If glucagon is, in fact, a major hormonal force in the regulation of new glucose formation, it is reasonable to expect that its secretion would be stimulated by a rise in the concentration of alanine, the precursor, as it is inhibited by a rise in the concentration of glucose, the product (4). Because no information concerning the influence of alanine upon the hormones of the islets of Langerhans is available, studies were undertaken to determine the effect of this key amino acid upon the secretion of glucagon and insulin.

\section{METHODS}

Adult mongrel dogs weighing between 14 and $25 \mathrm{~kg}$ were used. In one series of experiments, a fine $\mathrm{T}$-catheter was implanted in the pancreaticoduodenal vein, as reported previously (5). The patency of the catheter was maintained during the postoperative period by means of a constant infusion of heparinized saline $(10,000 \mathrm{USP} U$ of heparin/ 1,000 $\mathrm{ml}$ saline per 12-18 hr). Experiments were carried out 3 or 4 days after the operation. In a second series of dogs, a plastic tubing was inserted via the jugular vein into the inferior vena cava or right auricle of the heart.

$1 \mathrm{mmole}$ or 0.1 mmole L-alanine (Sigma Chemical Co., St. Louis, Mo.) per $\mathrm{kg}$ of body weight was dissolved in either 40 or $120 \mathrm{ml}$ of distilled water. The solution was neutralized with $\mathrm{NaOH}$ to a $\mathrm{pH}$ between 7 and 7.5.

Blood specimens were obtained from either the pancreaticoduodenal vein or from the vena cava with syringes rinsed 


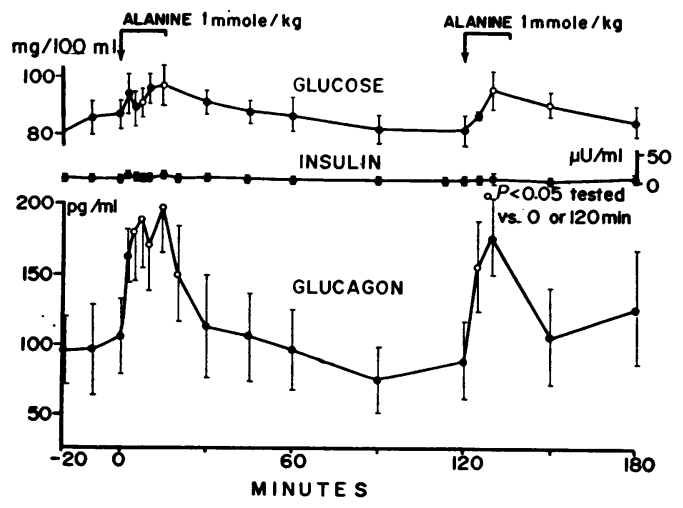

FIGURE 1 The mean response $( \pm \mathrm{SEM})$ of inferior vena caval plasma glucagon, insulin, and glucose concentrations of four conscious dogs to $1 \mathrm{mmole}$ of alanine per $\mathrm{kg}, 0.25$ mmole per $\mathrm{kg}$ of which was administered as a priming injection and 0.75 mmole per $\mathrm{kg}$ during the remainder of the $15 \mathrm{~min}$ period. The open circles indicate statistically significant points $(P<0.05$ tested vs. 0 or $120 \mathrm{~min})$.

with a $10 \%$ solution of EDTA and were transferred immediately into chilled tubes containing $0.1 \mathrm{ml}$ of Trasylol ${ }^{1}$ (500 Kallikrein Inactivator $U$ per $\mathrm{ml}$ blood). The plasma was separated immediately and stored at $-15^{\circ}$ to $-20^{\circ} \mathrm{C}$ for up to $13 \mathrm{wk}$.

Glucose concentration was measured by the ferricyanide method of Hoffman (6) using a Technicon AutoAnalyzer (Technicon Corp, Tarrytown, N. Y.). Insulin was determined by the radioimmunoassay of Yalow and Berson (7) using the Herbert modification (8). Glucagon was assayed by radioimmunoassay as most recently modified (9) using antiserum $30 \mathrm{~K}$, which is highly specific for pancreatic glucagon and cross-reacts very weakly with gastrointestinal glucagonlike immunoreactivity. For statistical analysis, Student's $t$ test for paired data was employed.

In the experiments with administration of the larger dose of alanine, plasma alanine concentrations were kindly determined by Dr. T. T. Aoki using conventional ion exchange, column chromatography. In the experiments with administration of the low dose of alanine, plasma levels were determined by Dr. Roberto Parrilla (also of the Elliott P. Joslin Research Laboratory, Harvard Medical School, Boston, Mass.) using competitive binding with isotopicallylabeled alanine to bacterial transfer-RNA. ${ }^{2}$

\section{RESULTS}

Effect of a high dose alanine infusion. To determine the effect of a high alanine level upon alpha cell secretion, a rapid priming injection of 0.25 mmoles per $\mathrm{kg}$ of the amino acid followed by an infusion of 0.75 mmoles per $\mathrm{kg}$ during a period of $15 \mathrm{~min}(0.05 \mathrm{mmole} / \mathrm{kg}$ per $\mathrm{min}$ ) was given to four dogs. At $15 \mathrm{~min}$, an alanine level of $3766 \mu_{\mathrm{M}}(\mathrm{SEM} \pm 545)$ was observed. Glucagon, measured in the peripheral venous blood, rose within $2 \frac{1}{2}$ min from a mean base line value of $107 \mathrm{pg}$ per $\mathrm{ml}$ (SEM \pm 26$)$ and reached a peak level of $197 \mathrm{pg}$ per $\mathrm{ml}$ $(\operatorname{SEM} \pm 32)$ at the end of the 15-min infusion (Fig. 1).

${ }^{1}$ FBA Pharmaceuticals, Inc., New York.

${ }^{2}$ Method to be published.
This striking rise was observed in all four animals tested and was statistically significant $(P<0.05$ at 5,10 , and $20 \mathrm{~min}$ and $P<0.01$ at $7 \frac{1}{2}$ and $15 \mathrm{~min}$ ). When the same dose of alanine was repeated at $120 \mathrm{~min}$, a similar rise was observed in all four dogs; however, by paired analysis, only the $125 \mathrm{~min}$ value was significantly higher than the $120 \mathrm{~min}$ level $(P<0.01)$. The mean maximal rise in glucagon was $95 \mathrm{pg}$ per $\mathrm{ml}(\mathrm{SEM} \pm 10)$ during the first infusion period and $103 \mathrm{pg}$ per $\mathrm{ml}$ (SEM \pm 24 ) during the second, representing a $100 \%$ increase above base line.

Plasma insulin rose from a mean level of $3 \mu \mathrm{U}$ per ml ( $\operatorname{SEM} \pm 2$ ) to $11 \mu \mathrm{U}$ per $\mathrm{ml}$ ( $\operatorname{SEM} \pm 4$ ), but this increase was not statistically significant $(P>0.05)$. The mean maximal insulin rise during all infusions was $9 \mu \mathrm{U}$ per $\mathrm{ml}$ (SEM \pm 3 ).

Plasma glucose increased significantly from a mean fasting level of $87 \mathrm{mg}$ per $100 \mathrm{ml}$ (SEM \pm 5 ) to a peak of $97 \mathrm{mg}$ per $100 \mathrm{ml}(\mathrm{SEM} \pm 7)$ at the end of the infusion $(P<0.05)$. A similar response accompanied the second infusion of alanine. The mean maximal rise was $15 \mathrm{mg}$ per $100 \mathrm{ml}(\mathrm{SEM} \pm 3)$ and $16 \mathrm{mg}$ per $100 \mathrm{ml}$ ( $\operatorname{sEM} \pm 3$ ) for the two infusion periods.

Effect of an alanine infusion during $60 \mathrm{~min}$. The plasma concentrations of alanine attained in the foregoing experiments are far above the physiologic range and must be regarded as pharmacologic. In order to determine if a lower dose of the amino acid would influence the secretion of glucagon, the same 1 mmole per $\mathrm{kg}$ of alanine was administered to four dogs over a $60 \mathrm{~min}$ rather than $15 \mathrm{~min}$ period, a rate of $0.017 \mathrm{mmole} / \mathrm{kg}$ per min, and the priming injection was omitted. In these experiments, islet cell hormones were measured in the pancreaticoduodenal vein. Alanine, measured in two dogs, rose from 30 to $80 \%$ above the preinfusion level during

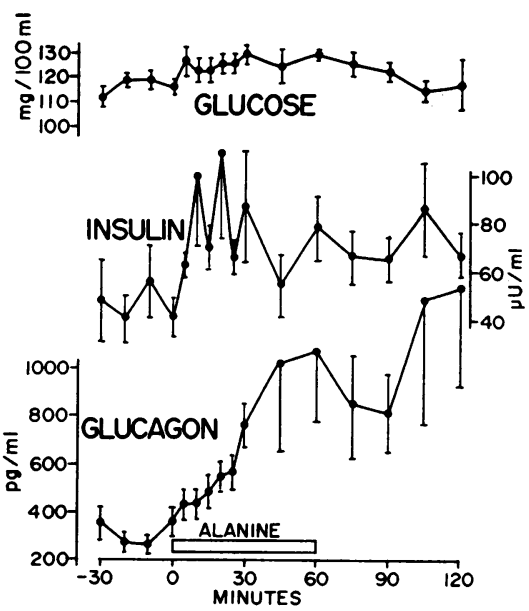

FIGURE 2 The mean response ( \pm SEM) of glucagon, insulin, and glucose to the infusion in four conscious dogs of $1 \mathrm{mmole}$ of alanine per $\mathrm{kg}$ over a $60 \mathrm{~min}$ period. The blood samples were obtained from the pancreaticoduodenal vein. 
the first $15 \mathrm{~min}$ and from 50 to $120 \%$ after $30 \mathrm{~min}$, well within the physiologic range of change (10).

Glucagon rose immediately from a preinfusion average of $358 \mathrm{pg}$ per $\mathrm{ml}$ (SEM \pm 60 ) to $1066 \mathrm{pg}$ per $\mathrm{ml}$ (SEM \pm 292 ) at $60 \mathrm{~min}$ (Fig. 2). An increment was observed in all five dogs and was statistically significant at $30 \mathrm{~min}$ $(P<0.02)$. The postinfusion rise in glucagon is unexplained and alanine measurements at these times were not performed. The insulin level in the pancreaticoduodenal vein rose intermittently, forming multiple peaks, only one of which differed significantly from the base line values $(P<0.05)$. Glucose concentration increased approximately $10 \mathrm{mg}$ per $100 \mathrm{ml}$ to peak values of $130 \mathrm{mg}$ per $100 \mathrm{ml}$ at 30 and $60 \mathrm{~min}$.

Effect of hyperglycemia upon alanine-induced glucagon secretion. If the purpose of alanine-induced glucagon secretion is to increase gluconeogenesis from alanine when exogenous glucose is not available, one might anticipate that an abundance of exogenous glucose, which would render this function unnecessary, might abort the alpha cell response. For this reason, the effect of hyperglycemia upon the glucagon response to alanine was tested in four dogs during an infusion of glucose at a rate of $0.9 \mathrm{~g} / \mathrm{kg}$ per hr.

A priming injection of 0.25 mmole per $\mathrm{kg}$ of alanine, followed by an infusion of alanine at a rate of 0.75 mmole per $\mathrm{kg}$ for $15 \mathrm{~min}$ failed to elevate plasma glucagon above the mean base line levels of $75 \mathrm{pg}$ per ml ( $\operatorname{SEM} \pm 37$ ), although small glucagon increments did occur (Fig. 3). The insulin rise induced by alanine was considerably greater during hyperglycemia than previously; the mean insulin concentration increased from $75 \mu \mathrm{U}$ per $\mathrm{ml}(\mathrm{SEM} \pm 13)$ before the alanine injection, to a peak of $181 \mu \mathrm{U}$ per $\mathrm{ml}$ (SEM \pm 47$) 7 \frac{1}{2} \mathrm{~min}$ after the beginning of the first alanine infusion and to a peak of $163 \mu \mathrm{U}$ per $\mathrm{ml}(\mathrm{SEM} \pm 24) 10 \mathrm{~min}$ after the start of the second one (Fig. 3). The mean maximal insulin rise of $124 \mu \mathrm{U}$ per $\mathrm{ml}(\mathrm{SEM} \pm 38)$ after the first alanine infusion was approximately ten times greater than that induced by alanine alone.

The effect of nonglucogenic amino acids on glucagon secretion. The fact that alanine-induced hyperglucagonemia is prevented by hyperglycemia has been interpreted as evidence that this alpha cell response is related to gluconeogenesis and is not merely a nonspecific response to an amino acid. In order to obtain additional support for such a relationship, the effect of two nongluconeogenic amino acids, leucine and valine, upon plasma glucagon was tested in four dogs. Each was infused at a rate of 1 mmole per $\mathrm{kg}$ of body weight during a $15 \mathrm{~min}$ period. In neither case did the concentration of glucagon rise significantly. In the four valine experiments, the mean fasting glucagon level was 123 pg per $\mathrm{ml}(\mathrm{SEM} \pm 26)$ and did not rise during the infusion, the highest glucagon value averaging $119 \mathrm{pg}$

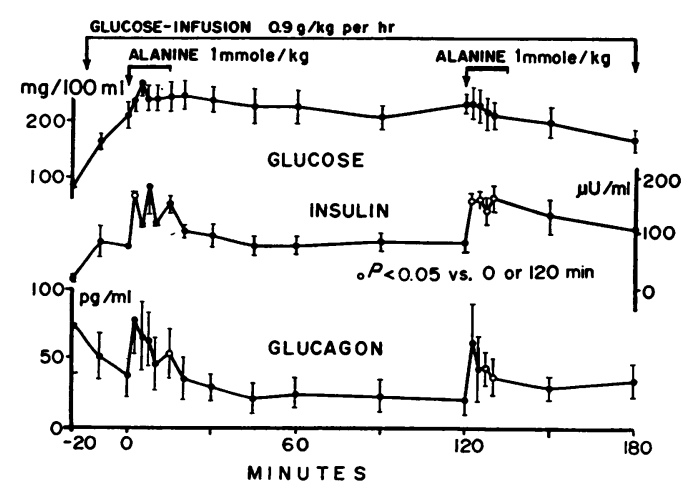

FIGURE 3 The effect of hyperglycemia induced by a constant glucose infusion in four conscious dogs upon the mean ( \pm SEM) inferior vena caval plasma glucagon, insulin, and glucose response to alanine administered as in the experiments of Fig. 1 ( $1 \mathrm{mmole}$ per $\mathrm{kg}$ in $15 \mathrm{~min}$ ).

per $\mathrm{ml}(\operatorname{SEM} \pm 12)$. In the case of leucine, infused at an identical rate, the fasting plasma glucagon level averaged $90 \mathrm{pg}$ per $\mathrm{ml}(\mathrm{SEM} \pm 11)$ and the highest value observed during the infusion was $95 \mathrm{pg}$ per $\mathrm{ml}$ (SEM \pm 8 ). A decline in glucagon to $65 \mathrm{pg}$ per $\mathrm{ml}$ ( $\mathrm{SEM}$ \pm 11 ) was observed at the end of the 15 min infusion but this change was not statistically significant.

\section{DISCUSSION}

The secretion of pancreatic glucagon has been shown previously to be stimulated by the infusion of arginine $(1,11,12)$ and arginine-containing amino acid mixtures (2), and by the ingestion of protein (13). It has been proposed (14) that this form of aminogenic glucagon secretion serves to prevent hypoglycemia from the associated aminogenic insulin secretion by replacing from the liver that glucose which accompanies the amino acids into cells. This, then, may be the primary purpose of the glucagon secretion which takes place during an influx of exogenous amino acids and any associated gluconeogenesis from exogenous precursors would, in a sense, be a secondary event which would serve to replenish glycogen stores presumably reduced by glucagon's early action. But if, in addition, glucagon is a significant determinant of the rate of the gluconeogenesis from endogenous precursors, such as occurs during starvation, one would expect its secretion to be influenced by the concentration of alanine, which Felig et al. have suggested to be a principal endogenous glucogenic substrate (3). The experiments described herein indicate that alanine is, indeed, a potent stimulus of the alpha cell secretion, and therefore, support the view that glucagon may be an important mediator of gluconeogenesis from endogenous as well as exogenous precursors. The 1 mmole per $\mathrm{kg}$ dose of alanine administered over $60 \mathrm{~min}$, which during the first $30 \mathrm{~min}$ raised the plasma alanine level only to the upper limit of physi- 
ologic change, i.e., $100 \%$ or so of the basal levels (10), elicited a striking rise of plasma glucagon.

The relationship of the alpha cell response to alanine to endogenous gluconeogenesis is, in a sense, supported by the beta cell response to alanine. In contrast to the effect of protein ingestion and arginine infusion (12, 13), alanine does not raise peripheral venous insulin levels; failure of alanine to stimulate as much secretion of the antigluconeogenic hormone, insulin, in parallel with the secretion of the gluconeogenic hormone, glucagon, as does protein or arginine suggests that alanine, as an endogenous substrate, is directed by glucagon towards gluconeogenesis without much opposition from insulin. In contrast, after protein or arginine, the insulin rise and the higher ratio of insulin to glucagon suggests that a higher fraction of these exogenous amino acids is being channeled into protein synthesis, rather than towards gluconeogenesis.

Furthermore, when need for gluconeogenesis was abolished by inducing hyperglycemia by means of a glucose infusion, the infusion of alanine did not raise plasma glucagon above the fasting level, but did stimulate insulin secretion; in other words, when gluconeogenesis was unnecessary, alanine caused a rise rather than a decline in the ratio of insulin to glucagon, which would tend to reduce the rate of gluconeogenesis. The influence of alanine upon the secretion of the alpha and beta cells may thus vary according to the availability of exogenous glucose; during glucose lack it stimulates the secretion of glucagon, not insulin, while during glucose abundance, it stimulates insulin and has relatively little effect on glucagon. The fact that the nonglucogenic amino acids, valine and leucine, administered at the high $1 \mathrm{mmole} / \mathrm{kg}$ per $15 \mathrm{~min}$ dose failed to stimulate glucagon secretion lends a modicum of additional support to the concept that alanine-induced glucagon secretion may be truly related to gluconeogenesis rather than a relatively nonspecific effect of amino acid administration.

Marliss, Aoki, Unger, Soeldner, and Cahill have reported that in prolonged starvation physiologic increments in glucagon induced by the infusion of crystalline glucagon cause an increase in the extraction of alanine by the liver (15). This finding and the results of the present study are consonant with the concept of glucagon mediation of endogenous gluconeogenesis from alanine. The alpha cell may well play a central role in the "glucose-alanine cycle," with its secretory output influenced positively by the alanine level and negatively by the glucose level.

\section{ACKNOWLEDGMENTS}

The authors wish to express their thanks to Mrs. Margaret Bickham, Mrs. Brenda Mendenhall, Mrs. Shirley Harvey, and Mrs. Genevieve Thompson for their technical assistance, and to Doctors Roberto Parrilla and Thomas Aoki of Boston for performing the alanine determinations.

This work was supported by National Institutes of Health Grant AM 02700-12; Hoechst Pharmaceutical Co., Somerville, N. J.; The Upjohn Co., Kalamazoo, Mich.; Pfizer Laboratories, New York; Bristol-Myers Co., New York; Mead Johnson Laboratories, Evansville, Ind.; Eli Lilly and Company, Indianapolis, Ind.; and the Dallas Diabetes Association, Dallas, Tex.

\section{REFERENCES}

1. Unger, R. H., E. Aguilar-Parada, W. A. Müller, and A. M. Eisentraut. 1970. Studies of pancreatic alfa-cell function in normal and diabetic subjects. J. Clin. Invest. 49: 837.

2. Ohneda, A., E. Aguilar-Parada, A. M. Eisentraut, and R. H. Unger. 1968. Characterization of response of circulating glucagon to intraduodenal and intravenous administration of amino acids. J. Clin. Invest. 47: 2305.

3. Felig, P., T. Pozefsky, E. Marliss, and G. F. Cahill, Jr. 1970. Alanine: key role in gluconeogenesis. Science (Washington). 167: 1003.

4. Ohneda, A., E. Aguilar-Parada, A. M. Eisentraut, and R. H. Unger. 1969. Control of pancreatic glucagon secretion by glucose. Diabetes. 18: 1 .

5. Unger, R. H., A. Ohneda, I. Valverde, A. M. Eisentraut, J. Exton, V. Harris, A. M. Jones, and G. Thompson. 1968. Characterization of the responses of circulating glucagon-like immunoreactivity to intraduodenal and intravenous administration of glucose. J. Clin. Invest. 47: 48.

6. Hoffman, W. S. 1937. A rapid photoelectric method for the determination of glucose in blood and urine. J. Biol. Chem. 120: 51 .

7. Yalow, R. S., and S. A. Berson. 1960. Immunoassay of endogenous plasma insulin in man. J. Clin. Invest. 39: 1157.

8. Herbert, V., K-S Lau, C. W. Gottlieb, and S. J. Bleicher. 1965. Coated charcoal immunoassay of insulin. J. Clin. Endocrinol. Metab. 25: 1375.

9. Aguilar-Parada, E., A. M. Eisentraut, and R. H. Unger. 1969. Pancreatic glucagon secretion in normal and diabetic subjects. Amer. J. Med. Sci. 257: 415.

10. Felig, P., and J. Wahren. 1971. Interrelationship between amino acid and carbohydrate metabolism during exercise: the glucose-alanine cycle. In Muscle Metabolism during Exercise. B. Pernow and B. Saltin, editors. Plenum Publishing Corporation, New York. 206.

11. Assan, R., G. Rosselin, and J. Dolais. 1967. Effets sur la glucagonémie des perfusions et ingestions d'acides aminés. J. Ann. Diabèt. Hôtel Dieu. 7: 25.

12. Fajans, S. S., J. C. Floyd, Jr., R. F. Knopf, and J. W. Conn. 1967. Effect of amino acids and proteins on insulin secretion in man. Recent Progr. Hormone Res. 23: 617.

13. Muller, W. A., G. R. Faloona, E. Aguilar-Parada, and R. H. Unger. 1970. Abnormal alpha-cell function in diabetes: response to carbohydrate and protein ingestion. N. Engl. J. Med. 283: 109.

14. Unger, R. H., A. Ohneda, E. Aguilar-Parada, and A. M. Eisentraut. 1969. The role of aminogenic glucagon secretion in blood glucose homeostasis. J. Clin. Invest. 48: 810.

15. Marliss, E. B., T. T. Aoki, R. H. Unger, S. J. Soeldner, and G. F. Cahill, Jr. 1970. Glucagon levels and metabolic effects in fásting man. J. Clin. Invest. 49: 2256. 